\title{
THE ASSESSMENT OF CHEMICAL AND ECOLOGICAL STATUS IN THE WATER BODIES OF SLOCENE AND AGE
}

\author{
*Kristīne Ikauniece, Ainis Lagzdiṇ̌̌ \\ Latvia University of Life Sciences and Technologies, Latvia \\ *Corresponding author's email: kristine.ikauniece@inbox.lv
}

\begin{abstract}
Small rivers are important in terms of water quantity and quality as these rivers collect and deliver water to medium and large rivers downstream. Due to low water flow and high connectivity to adjacent land, small rivers are highly vulnerable to changes caused by natural and anthropogenic factors. This paper aims to assess the chemical and ecological quality of two small rivers including the Slocene and Age as related to dominant land use cover in the contributing area of these water bodies. The effects of land-use patterns and concentrations of chemical substances $\mathrm{TN}, \mathrm{NO}_{3}^{-}-\mathrm{N}, \mathrm{NH}_{4}^{+}-\mathrm{N}, \mathrm{TP}$ and $\mathrm{PO}_{4}^{2-}-\mathrm{P}$ in river waters will be determined. The highest concentration of total nitrogen (TN) as measured in the Slocene river was $21 \mathrm{mg} \mathrm{L}^{-1}$ in spring, while the lowest concentration of TN was $0.86 \mathrm{mg} \mathrm{L}^{-1}$ in autumn. The highest concentration of total phosphorus (TP) in the Slocene river was $0.14 \mathrm{mg} \mathrm{L}^{-1}$ in late summer, the lowest was $0.03 \mathrm{mg} \mathrm{L}^{-1}$ in late autumn. Similarly, in the Age river, the highest concentration of TN was $4.90 \mathrm{mg}$ $\mathrm{L}^{-1}$ in spring, while TN the lowest concentration of TN was $0.51 \mathrm{mg} \mathrm{L}^{-1}$ in late autumn. The highest concentration of TP in the Age river was $0.3 \mathrm{mg} \mathrm{L}^{-1}$ in summer, while the lowest $0.05 \mathrm{mg} \mathrm{L}^{-1}$ in autumn.
\end{abstract}

Key words: agricultural land, forests, chemical and ecological status, nitrogen, phosphorus.

\section{Introduction}

An important component of surface waters is small rivers, the amount of which in Latvia is about $6 \%$ of the total number of river streams (Apsīte, 2018). According to the national river classification system, these rivers are up to $100 \mathrm{~km}$ in length. Rivers of this type are the most vulnerable and susceptible to changes in environmental conditions and anthropogenic activities. Poorly managed anthropogenic activities near small rivers may deteriorate the quality of water ecosystems. Large inputs of plant nutrients from agricultural land improves water fertility coursing increased the growth of algae in both inland and seawaters (Nixon, 1995; Kḷviñš \& Springée, 2011; Voss et al., 2011). Agriculture alone contributes about $80 \%$ of the total diffuse load of nitrogen to the Baltic Sea (HELCOM, 2009; Voss et al., 2011).

The smallest particles of soil are colloids, which define the extent and quality of physico-chemical processes in the soil. Soils with relatively high positively charged colloids exhibit more active exchange reactions with the anions of the chemicals in the fertilizers (Nikodemus et al., 2008). Plants can take up to $30-50 \%$ of used chemical fertilizers, the remaining part of applied chemicals stay in the soil until it flows away in runoff processes (Mozner, Andrea, \& Csutora, 2012). The following forms of nitrogen and phosphorus are considered as nutrients in waters - nitrogen in inorganic ions $\left(\mathrm{NH}_{4}^{+}, \mathrm{NO}_{2}^{-}, \mathrm{NO}_{3}\right.$ ) and organic compounds of nitrogen, phosphorus in inorganic ions $\left(\mathrm{PO}_{4}^{3-}, \mathrm{HPO}_{4}^{2-}, \mathrm{H}_{2} \mathrm{PO}_{4}^{-}\right.$, polyphosphates) and organic compounds of phosphorus (Kḷaviņs \& Cimdiņš, 2004). In the best case, the plants will use $50 \%$ of the total amount of fertilizer applied on the soil, 2-20\% will be lost in evaporation processes, $15-25 \%$ will interact with the clay particles and last $2-10 \%$ will enter surface waters (Savci, 2012).
According to soil characteristics and climatic conditions, relatively high amounts of nitrogen are converted into nitrates due to nitrification processes in the soil. Negatively charged nitrate ions are poorly adsorbed to the soil particles, they remain in the soil solution and are flushed away, for example during heavy rainfalls (Nikodemus et al., 2008). Most soils have a high phosphorus binding capacity, so phosphorus leaching from the soil is low in most cases. Up to $90 \%$ of the phosphorus is in the form of organic compounds or can be bound to the suspended particles. Phosphorus is transported in dissolved or particulate form. In the form of suspended particles, it is subjected to the water flow and forms the most part of the phosphorus leakage from arable land (Klaviņs \& Cimdiņš, 2004; Nikodemus et al., 2008). The influx of pollutants is determined by the turbidity of the substances accumulated in the sediment phase and by the surface runoff from agricultural areas. In autumn, the amount of nutrients is influenced by surface runoff and decomposition of organic matter in the body of water itself (Klaviņšs \& Cimdin̄š, 2004).

Leaching of nitrates and phosphates is an endless process, the second most important cause of diffuse pollution is leaching of organic matter from forest areas which is intensified by cutting down and draining forested areas (Latvijas Vides, ǵeologijas..., 2009). Small discharges from manure storage and dairies, dry toilets, silos and septic tanks are also considered as diffuse pollution (Latvijas Vides, ǵeologijas..., 2015a).

The chemical contamination of waters with nutrients are characterized by the presence of nitrogen compounds such as total nitrogen (TN), nitrate-nitrogen $\left(\mathrm{NO}_{3}^{-}-\mathrm{N}\right)$, and ammonium nitrogen $\left(\mathrm{NH}_{4}^{+}-\mathrm{N}\right)$, and presence of phosphorus compounds such as total phosphorus (TP) and orthophosphate phosphorus $\left(\mathrm{PO}_{4}^{2-}-\mathrm{P}\right)$ (Kḷaviņš \& Cimdiņš, 2004; 
Havlin et al., 2005). In clean waters, TN varies from 0.1 to $0.5 \mathrm{mg} \mathrm{L}^{-1}$, concentrations above $1 \mathrm{mg} \mathrm{L}^{-1}$ indicate anthropogenic pollution. TN is also used as an indicator of the degree of eutrophication in the seas (Nixon, 1995; Kḷaviņš \& Cimdiņš, 2004; Kḷaviņš \& Sprinǵe, 2011). Total phosphorus is a good indicator of the anthropogenic impact on water quality (Nixon, 1995; Kḷaviňš \& Cimdin̄š, 2004). For low-impact waters, the concentration of TP is less than $0.05 \mathrm{mg}$ $\mathrm{L}^{-1}$. TP is also used as an indicator of the degree of eutrophication in lakes (Nixon, 1995; Kḷaviṇš \& Cimdiņš, 2004; Kḷaviņš \& Springǵe, 2011). The main objective of this paper is to assess the chemical and ecological quality of two small rivers located in different regions in Latvia with specific hydrological conditions and land use.

\section{Materials and Methods}

The selected rivers of Slocene and Age are located in different parts of Latvia, representing regions with similar climate, but different meteorological conditions, soil texture and farming intensity. All Latvian rivers are divided into six types by its length, river basin area and flow rate (Cabinet of Ministers, 2004).

The Slocene River is a moderate type ritral river (Latvijas Vides, geologijas..., 2015a) located in the northwestern part of Latvia. The soil texture within the river basin mainly is sandy loam (Nikodemus et al., 2008). The farming in this catchment is moderately intensive, $82.3 \mathrm{~km}^{2}$ of the total river basin area is agricultural land (European Environment Agency, 2018). According to Latvijas Vides, geologijas..., 2005 the average TN concentration in this river is $3.5-4.5 \mathrm{mg} \mathrm{L}^{-1}$ which is rated as being high, but TP is $>0.18 \mathrm{mg} \mathrm{L}^{-1}$ rated as very high.

The Age River is a moderate type ritral river (Latvijas Vides, geologijas..., 2015b) situated in the northeastern part of Latvia. The soil texture within river basin mainly is sandy clay (Nikodemus et al., 2008). The farming in this river basin is moderately intensive, $95.5 \mathrm{~km}^{2}$ of the total river basin area is agricultural land (European Environment Agency, 2018). The average TN concentration is $1.5-2.5 \mathrm{mg}$ $\mathrm{L}^{-1}$ rated as moderate, but TP is $<0.06 \mathrm{mg} \mathrm{L}^{-1}$ rated as very low (Latvijas Vides, ǵeoloǵijas..., 2005). Main characteristics of the selected rivers are compiled in Table 1.

Both rivers are moderately deep with a stream speed of $>0.2 \mathrm{~m} \mathrm{~s}^{-1}$. The bottom substrate is formed from sand, gravel and stones (Latvijas Vides, geologiijas..., 2015a, 2015b).

The main diffuse pollution sources are agriculture and background pollution from forests. The Corine Land Cover 2018 database (European Environment Agency, 2018) information is used to obtain the basic data for evaluation. According to the information summarized, a specific area of agricultural land and forested land in each water body is expressed as a parameter relative to the total area of the water body. The calculated percentage of agricultural land and forests is converted into points where high quality is 1 point, good quality is 2 points, medium quality is 3 points, poor quality is 4 points and very poor quality is 5 points (Latvijas Vides, ǵeoloǵijas..., 2015a, 2015b). The assessment values are developed for each river type, values for assessment of ecological status in moderate ritral rivers are shown in Table 2.

The concentrations of $\mathrm{TN}, \mathrm{NO}_{3}^{-}-\mathrm{N}, \mathrm{NH}_{4}^{+}-\mathrm{N}$, TP and $\mathrm{PO}_{4}^{2-}-\mathrm{P}$ in river waters were analyzed. Samples in the river were taken between 2007 and 2018 with various intervals. Water samples were filled into 1.5 L pure plastic bottles and delivered to the Latvia Environment, Geology and Meteorology Centre laboratory for analysis. TN concentrations were determined by the LVS EN 12260:2004 method

Main characteristics of the selected rivers

Table 1

(Latvijas Vides, ğeologijas..., 2015a; 2015b; European Environment Agency, 2018)

\begin{tabular}{|c|c|c|c|}
\hline River & Type & Length, $\mathrm{km}$ & Total catchment area, $\mathrm{km}^{2}$ \\
\hline Slocene & Moderate ritral & 49.05 & 241.7 \\
\hline Age & Moderate ritral & 40.33 & 202.03 \\
\hline
\end{tabular}

Table 2

Values for assessment of ecological status in moderate ritral rivers

(Latvijas Vides, ǵeologijas..., 2015a, 2015b)

\begin{tabular}{|c|c|c|c|c|c|}
\hline & High & Good & Medium & Poor & Very poor \\
\hline Agricultural area & $<0.089$ & $0.089-0.240$ & $0.240-0.391$ & $0.391-0.441$ & $>0.441$ \\
\hline Forests & $<1.416$ & $1.416-1.544$ & $1.544-1.673$ & $1.673-1.801$ & $>1.801$ \\
\hline
\end{tabular}


(Latvian Standard, 2004a), $\mathrm{NO}_{3}-\mathrm{N}$ concentrations were determined by the LVS EN ISO 13395:2004 method (Latvian Standard, 2004b), $\mathrm{NH}_{4}^{+}-\mathrm{N}$ concentrations were determined by the LVS EN ISO 11732:2005 method (Latvian Standard, 2005a), TP and $\mathrm{PO}_{4}^{2}-\mathrm{P}$ concentrations were determined by the LVS EN ISO 6878:2005 method (Latvian Standard, 2005b).

To assess the importance of diffuse pollution sources the basic data on the distribution of agricultural land and forests in each water body was calculated. To compare data statistically, the analysis of onefactor linear regression was conducted. Changes in the concentrations of nitrogen and phosphorus compounds depending on the sampling time are considered significant $(\mathrm{p} \leq 0.05)$ if the concentrations of leached chemical compounds increase in spring and autumn but decrease in summer and winter.

The assessment of the water quality of the Age and Slocene rivers has been made according to Water Framework Directive 2000/60/EC and the Nitrate Directive 91/676/EEC instructions and threshold values for surface water body water quality assessment, which in Latvia are integrated into CM Regulation No.118 'Regulation of quality of surface water and groundwater'.

\section{Results and Discussion}

Latvia is located in a humid climate zone with mild weather conditions, where rainfalls exceed evaporation and access water drains into watercourses (Jansons et $a l ., 2003)$. The specific runoff of a river is affected by the amount of rainfall at each location over the given period of time (Randall \& Mulla, 2001; Iital, 2005). The annual precipitation rate in the northwestern part of the Venta River basin district is $650-700 \mathrm{~mm}$, but in the northeastern part of the Gauja River basin district is 700-750 mm (Latvijas Vides, geologijas..., 2015a, 2015b). The maximum amount of precipitation is measured in August, while minimum in February. According to water body specific precipitation rates, the annual runoff in the Slocene River is $220 \mathrm{~mm}$, while in the Age River $280 \mathrm{~mm}$ (Latvijas Vides, geologijas..., 2015a, 2015b). The runoff differences between the selected research sites strongly depend on the amount of precipitation. It has been found that runoff from subsurface drainage is the main nutrient transport route from soil profiles to streams - therefore, for analyzing nutrient concentrations in water, the climatic and hydrological conditions of the research site must be taken into account (Randall \& Mulla, 2001; Iital, 2005).

In order to determine which sources of diffuse pollution are significant, there is a need to assess whether the values of the land use characterizing economic activities are not close to the limit values above which the ecological quality of water bodies is deteriorating. In the current intensity of economic activity in Latvia, the most significant diffuse pollution loads are characterized by the proportion of agricultural land and forests in the water body (Latvijas Vides, ǵeologijas..., 2015a).

The total catchment area of the Slocene River basin is $241.8 \mathrm{~km}^{2}$, main land-use types are artificial surfaces, agricultural areas, forests, wetlands and water bodies (Figure 1). Agricultural lands of the Slocene River consists of non-irrigated arable land, fruit trees and berry plantations, pastures, complex cultivation patterns and land principally used in agriculture, which is about $34.5 \%$ of the total catchment area. Near the Slocene River broad-leaved, coniferous, mixed forests, natural grasslands and transitional woodland shrubs are growing, which is about $48.8 \%$
$\widehat{A}_{N}$

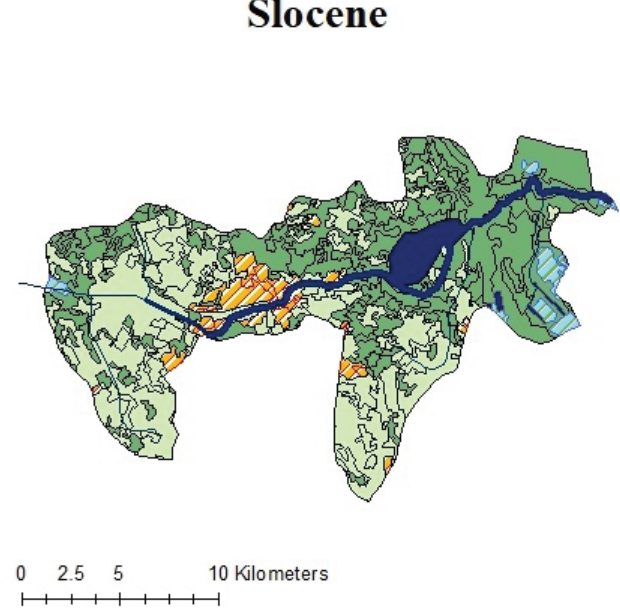

Slocene

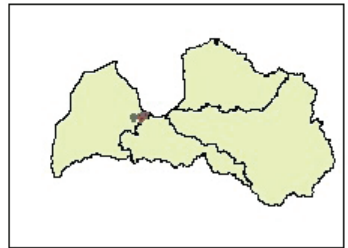

Land-use types

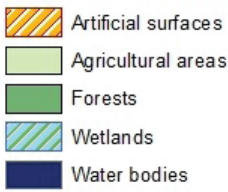

Figure 1. Land use in the Slocene River basin. 


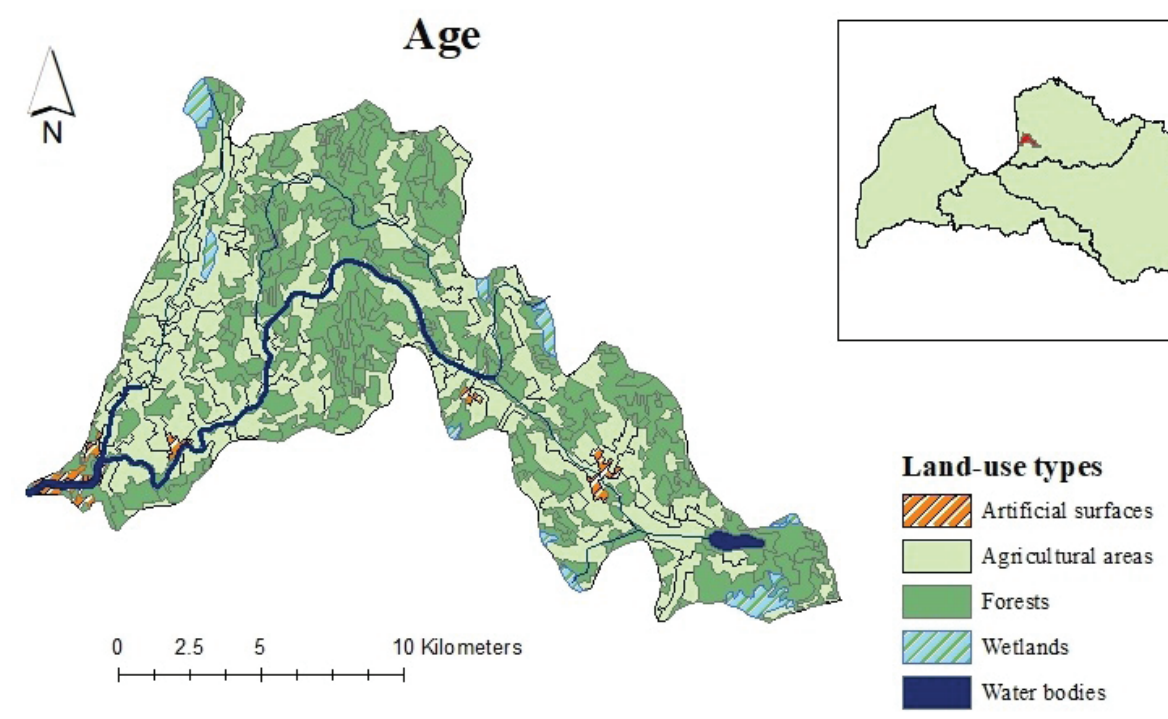

Figure 2. Land use in the Age River basin.

Main land use types of the Slocene and Age River basins

\begin{tabular}{|c|c|c|c|}
\hline River & $\begin{array}{c}\text { Total catchment area, } \\
\mathrm{km}^{2}\end{array}$ & $\begin{array}{c}\text { Agricultural area, } \\
\mathrm{km}^{2}\end{array}$ & $\begin{array}{c}\text { Forests, } \\
\mathrm{km}^{2}\end{array}$ \\
\hline Slocene & 241.8 & 83.3 & 118.08 \\
\hline Age & 202.03 & 95.5 & 96.96 \\
\hline
\end{tabular}

of the total catchment area (European Environment Agency, 2018).

The total catchment area of the Age River basin is $202.03 \mathrm{~km}^{2}$, main land-use types are artificial surfaces, agricultural areas, forests, wetlands and water bodies (Figure 2). Agricultural lands of the Age River consists of non-irrigated arable land, pastures, complex cultivation patterns and land principally used in agriculture, which is about $47.3 \%$ of the total catchment area (European Environment Agency, 2018). Total catchment area, agriculture land and forest occupied area of the selected river basins are compiled in Table 3.

According to the methodology for the assessment of ecological status, the water quality in the Slocene river basin is evaluated as good, while in the Age River basin as very poor. In both river basins leaching risks of nutrients are high (Latvijas Vides, ǵeoloǵijas..., 2005), but a larger share of agricultural land in the Age River basin reflects lower ecological level of the river basin. According to the assessment of ecological status forests in both river basins have a high-quality class. This is due to the relatively large and unmodified forested areas. In the Venta River basin district, $20 \%$ of the total forest area is covered with forests, which have been drained to improve forest growth conditions and increase productivity (Latvijas Vides, geologijas..., 2015a). The same situation applies to the Gauja River basin district, where $60 \%$ of the land is covered with forests (Latvijas Vides, geologijas..., 2015b). The ecological status in both river basins is decreasing by the size of agricultural lands relative to the total

Table 4

Assessment of Ecological status for the Slocene and Age Rivers

\begin{tabular}{|c|c|c|c|c|c|}
\hline \multirow{2}{*}{$\begin{array}{c}\text { Basin } \\
\text { district }\end{array}$} & \multirow{2}{*}{ River } & \multicolumn{2}{|c|}{ Agricultural land } & \multicolumn{2}{c|}{ Forests } \\
\cline { 3 - 6 } & & Relation & Value & Relation & Value \\
\hline Venta & Slocene & 0.34 & 3 & 0.48 & 1 \\
\hline Gauja & Age & 0.47 & 6 & 0.47 & 1 \\
\hline
\end{tabular}




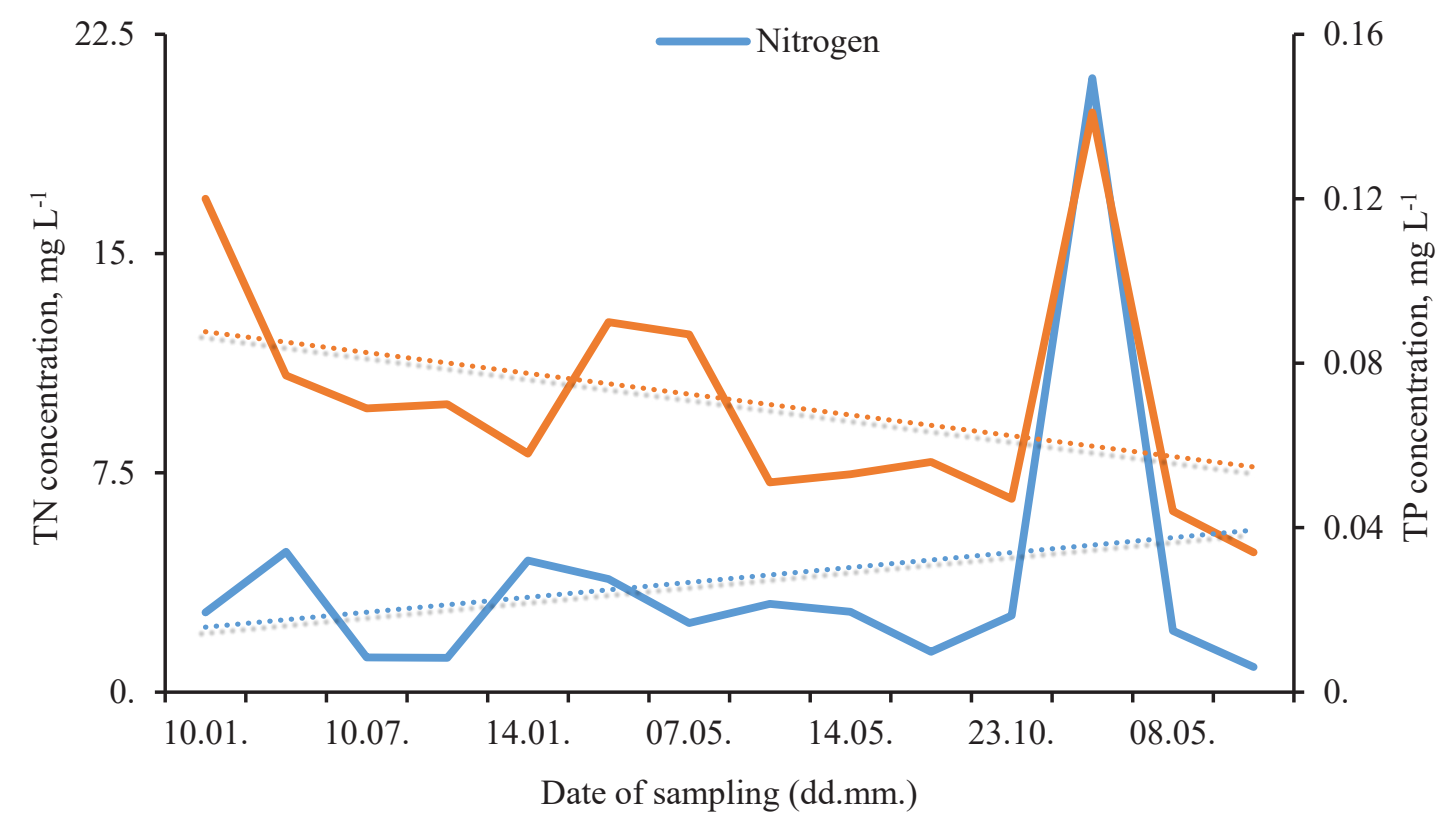

Figure 3. Total nitrogen and phosphorus concentrations in the Slocene River.

catchment area. Assessment of ecological status for the Slocene and Age rivers is shown in Table 4.

The changes in nutrient concentrations over time correlate with hydrological conditions. In both water bodies, the highest concentrations of nutrients were found in early spring and late autumn. In the Slocene river, the highest concentration of TN was $21 \mathrm{mg} \mathrm{L}^{-1}$ in spring, while the lowest concentration of $0.86 \mathrm{mg} \mathrm{L}^{-1}$ in autumn. The highest concentration of TP in the Slocene River was $0.14 \mathrm{mg} \mathrm{L}^{-1}$ in late summer, but the lowest of $0.03 \mathrm{mg} \mathrm{L}^{-1}$ in late autumn (Figure 3).
Similarly in the Age River, the highest concentration of TN was $4.90 \mathrm{mg} \mathrm{L}^{-1}$ in spring, while the lowest of $0.51 \mathrm{mg} \mathrm{L}^{-1}-$ in late autumn. The highest concentration of TP in the Age River was $0.3 \mathrm{mg} \mathrm{L}^{-1}$ in summer, but the lowest $0.05 \mathrm{mg} \mathrm{L}^{-1}-$ in autumn (Figure 4). Summary of nutrient concentrations in the selected rivers is shown in Table 5 .

A linear regression analysis of $\mathrm{TN}$ and $\mathrm{TP}$ concentrations as shown in Figure 3 and 4 indicate that over time the concentrations of TN decrease for the Age River and increase for the Slocene River.

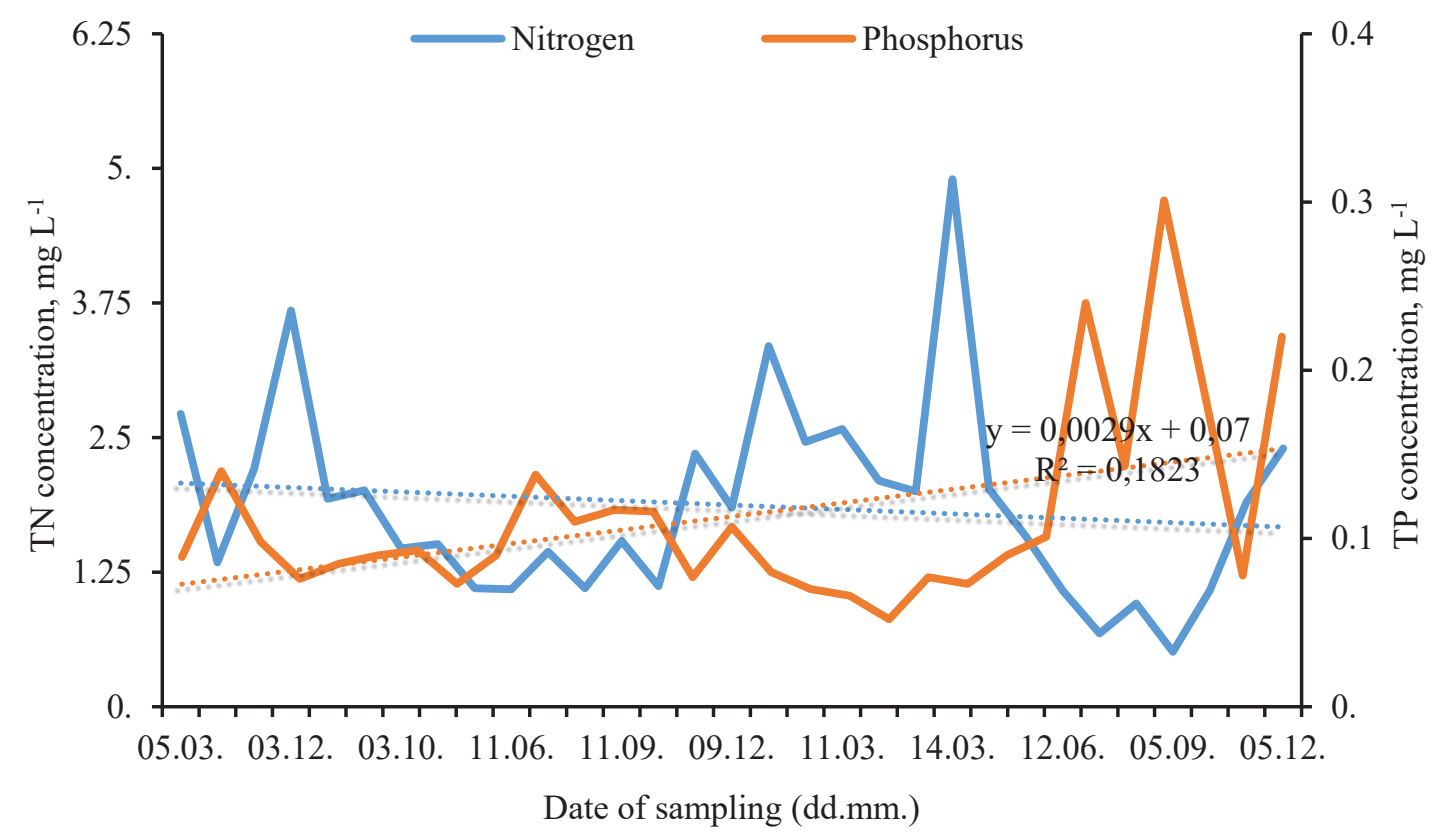

Figure 4. Total nitrogen and phosphorus concentrations in the Age River. 


\section{Nutrient concentrations in the selected rivers}

\begin{tabular}{|c|c|c|c|c|c|c|}
\hline \multirow{2}{*}{ Parameter } & \multirow{2}{*}{ Samples } & \multicolumn{3}{|c|}{ Values, mg L ${ }^{-1}$} & \multirow[b]{2}{*}{$\begin{array}{l}\text { Standard } \\
\text { Deviation }\end{array}$} & \multirow[b]{2}{*}{ Sample variance } \\
\hline & & Min & Max & Mean & & \\
\hline \multicolumn{7}{|c|}{ The Slocene river } \\
\hline $\mathrm{TN}$ & 14 & 0.86 & 21 & 3.88 & 5.07 & 25.74 \\
\hline $\mathrm{NO}_{3}^{-}-\mathrm{N}$ & 14 & 0.28 & 17.30 & 2.70 & 4.32 & 18.64 \\
\hline $\mathrm{NH}_{4}^{+}-\mathrm{N}$ & 14 & 0.05 & 0.28 & 0.15 & 0.07 & 0.005 \\
\hline TP & 14 & 0.03 & 0.14 & 0.07 & 0.01 & 0.0001 \\
\hline $\mathrm{PO}_{4}^{2-}-\mathrm{P}$ & 14 & 0.01 & 0.05 & 0.02 & 0.03 & 0.0009 \\
\hline \multicolumn{7}{|c|}{ The Age river } \\
\hline $\mathrm{TN}$ & 31 & 0.51 & 4.90 & 1.87 & 0.92 & 0.85 \\
\hline $\mathrm{NO}_{3}-\mathrm{N}$ & 31 & 0.09 & 2.90 & 0.94 & 0.67 & 0.45 \\
\hline $\mathrm{NH}_{4}^{+}-\mathrm{N}$ & 31 & 0.004 & 0.38 & 0.08 & 0.08 & 0.0057 \\
\hline $\mathrm{TP}$ & 28 & 0.05 & 0.30 & 0.11 & 0.06 & 0.003 \\
\hline $\mathrm{PO}_{4}^{2-}-\mathrm{P}$ & 28 & 0.02 & 0.16 & 0.06 & 0.038 & 0.0014 \\
\hline
\end{tabular}

In the case of TP concentrations, time trends are opposite, the concentrations increase and decrease for the Age River and Slocene River, respectively. Nutrient concentrations in rivers are characterized by seasonal variability. There is an increase in nutrient concentrations during spring floods and to lesser extents in autumn floods.

The model proposed by the authors is unsuccessful, all except the Age River model TN $\mathrm{p}=0.048$ with a level of confidence $95 \%$, is not relevant $p>0.05$. The date and month of analysis do not explain the levels of nutrient concentrations in the rivers. There is lack of information on the amount of precipitation and fertilizer amount in river basin areas, the temperature, etc.

Although the ecological status in the Age River is very poor, the annual mean concentrations of TN in the Age River is above-average values of TN concentrations of $1.5-2.5 \mathrm{mg} \mathrm{L}^{-1}$ (Latvijas Vides, geologijas..., 2005). Depending on the soil type, the Age River basin agricultural land is less fertilized, 30.5 $\mathrm{kg}$ of nitrogen and $1.98 \mathrm{~kg}$ of phosphorus per 1 hectare of land are released in the Gauja River basin per year (Latvijas Vides, geologijas..., 2015b). According to Latvian Environment, Geology and Meteorology Centre, $34.8 \mathrm{~kg}$ of nitrogen and $2.69 \mathrm{~kg}$ of phosphorus per 1 hectare of land are released in the Venta River basin per year (Latvijas Vides, ǵeologiijas..., 2015a). Nitrate-nitrogen $\left(\mathrm{NO}_{3}-\mathrm{N}\right)$ threshold level for good water quality according to the EU Commission (1991) is $11.3 \mathrm{mg} \mathrm{L}^{-1}$ which is equivalent to $50 \mathrm{mg} \mathrm{L}^{-1}$ nitrates $\left(\mathrm{NO}_{3}^{-}\right)$. This threshold value is not exceeded in the Slocene and Age Rivers with one exception in the Slocene River.

\section{Conclusions}

1. The ecological and chemical status of the Slocene and Age rivers depend on number of factors including soil type, climatic conditions, land use types, and anthropogenic activities.

2. The highest concentrations of nutrients have been measured during the spring period. This indicates that snow accumulation during the winter season is rather high in these waterbodies, and snow melt during the spring may cause increased nutrient losses from diffuse sources.

3. There is a need to implement edge-of-field practices such as sedimentation ponds, constructed wetlands, bottom dams, meandering, controlled drainage, and two-stage ditches in the Slocene and Age waterbodies in order to reduce nutrient losses from diffuse sources.

\section{References}

Apsīte, E. (2018). Virszemes ūdeni (Surface waters). In O. Nikodemus (Eds.) Latvija. Zeme, daba, tauta, valsts. (Latvia. Land, Nature, Nation, Country.) (pp. 273-321). Rīga, LU Akadēmiskais apgāds (in Latvian).

Cabinet of Ministers. (2004). Regulation No. 858 Regulations of Characterization, Classification, Quality Criteria of Surface Water Body Types for Determination of Anthropogenic Loads. Rīga: Latvijas Vēstnesis.

EU Commission. (1991). Directive 91/676/EEC: The protection of waters against pollution caused by nitrates from agricultural sources. Brussels: Official Journal of European Community, L 375, 1-8. 
EU Commission. (2000). Directive 2000/60/EC: Establishing a framework for the Community action in the field of water policy. Brussels: Official Journal of European Community, L 327, 1-72.

European Environment Agency. (2018). Copernicus Land Monitoring Service. Retrieved February 14, 2020, from https://www.copernicus.eu/en/services/land.

HELCOM. (2009). Eutrophication in the Baltic Sea - An integrated thematic assessment of the effects of nutrient enrichment and eutrophication in the Baltic Sea region. Helsinki: Finland, Baltic Sea Environmetal Proceedings No. 115B.

Havlin, J.L., Beaton, J.D., Tisdale, S.L., \& Nelson, W.L. (2005). Soil Fertility and Fertilizers: An Introduction to Nutrient Management ( $7^{\text {th }}$ ed.). New Jersey: Pearson Education.

Iital, A. (2005). Monitoring of surface water quality in small agricultural watersheds. Doctoral dissertation, Tallinn University of Technology, Estonia.

Jansons, V., Busmanis, P., Dzalbe, I., \& Kirsteina, D. (2003). Catchment and drainage field nitrogen balances and nitrogen loss in three agriculturally influenced Latvian watersheds. European Journal of Agronomy, 20 (1-2), 173-179. DOI: 10.1016/S1161-0301(03)00072-8.

Kḷaviņs, M., \& Cimdiņšs, P. (2004). Ūdeṇu kvalitāte un tās aizsardzība (Water Quality and its Protection). (pp. 49-54). Rīga: Latvia University (in Latvian).

Kḷaviņš, M., \& Spriņğe, G. (2011). Vides piesārņojums (Environmetal Pollution). In M. Kḷaviņš \& J. Zaḷoksnis (Eds.) Vide un ilgspējīga attīstība (Environment and Sustainable Development). (pp. 87-106). Rīga, LU Akadēmiskais apgāds (in Latvian).

Latvijas Vides, ğeolog̣ijas un meteorolog̣ijas ağentūra. (2005). Upju baseinu apgabalu raksturojums, antropogēno slodžu uz pazemes un virszemes ūdeņiem novērtējums, ekonomiskā analīze (Characteristics of river basin districts, assessment of anthropogenic pressures on groundwater and surface water, economic analysis). Rīga: Ministry of Environment (in Latvian).

Latvijas Vides, ǵeoloǵijas un meteoroloǵijas centrs. (2009). Izkliedētais piesārņojums (Diffuse pollution). Ventas upju baseinu apgabala apsaimniekošanas plāns 2010-2015. gadam (The Venta River basin district management plan for 2010-2015). (pp. 11-12). Rīga (in Latvian).

Latvijas Vides, ǵeoloǵijas un meteorologijas centrs. (2015a). Ventas upju baseina apsaimniekošanas plāns 2016-2021.gadam (The Venta River basin district management plan for 2016-2021). (pp. 22-48). Rīga (in Latvian).

Latvijas Vides, ǵeolog̣ijas un meteorolog̣ijas centrs. (2015b). Gaujas upju baseina apsaimniekošanas plāns 2016-2021.gadam (The Gauja River basin district management plan for 2016-2021). (pp. 20-41). Rīga (in Latvian).

Mozner, Z., Andrea, T., \& Csutora, M. (2012). Modifying the yield factor based on more efficient use of fertilizerThe environmental impacts of intensive and extensive agricultural practices. Ecological Indicators, 16, 58-66. DOI: 10.1016/j.ecolind.2011.06.034.

Nikodemus, O., Kārkliņš, A., Kḷaviņš, M., \& Melecis, V. (2008). Augsnes ilgtspējīga izmantošana un aizsardzība (Sustainable Use and Protection of Soil). Rīga, LU Akadēmiskais apgāds (in Latvian).

Nixon, S.W. (1995). Coastal marine eutrophication: a definition, social causes and future concerns Ophelia, 41, 199-219.

Randall, G.W., \& Mulla, D.J. (2001). Nitrate nitrogen in surface waters as influenced by climatic conditions and agricultural practices. Journal of Environment Quality, 30, 337-344. DOI: 10.2134/jeq2001.302337x.

Savci, S. (2012). An Agricultural Pollutant: Chemical Fertilizer. International Journal of Environmental Science and Development, 3, 77-79. DOI: 10.7763/IJESD.2012.V3.191.

Latvian Standard. (2004a). Latvian standard: Water quality: determination of nitrogen. LVS EN 12260:2004. Rīga.

Latvian Standard. (2004b). Latvian standard: Water quality: Spectrometric determination of nitrate nitrogen and total saturation by flow analysis. LVS EN ISO 13395:2004. Rīga.

Latvian Standard. (2005a). Latvian standard: Water quality: Ammonium nitrogen determination. the LVS EN ISO 11732:2005. Rīga.

Latvian Standard. (2005b). Latvian standard: Water quality: Determination of phosphorus. LVS EN ISO 6878:2005. Rīga.

Voss, M., Dippner, J.W., Humborg, C., Hürdler, J., Korth, F., Neumann, T., Schernewski, G., \& Venohr, M. (2011). History and scenarios of future development of Baltic Sea eutrophication. Estuarine, Coastal and Shelf Science Journal, 92, 307-322. DOI: 10.1016/j.ecss.2010.12.037. 